\section{Tendencies of Transformations in Rural Landscape of the Former Collective Farm Villages of Lithuania}

\section{Deividas Marcinkevičius*, Vilma Karvelytė Balbierienė}

Kaunas University of Technology, Department of Architecture and Urbanism Studentu St. 48, Kaunas 51367, Lithuania

*Corresponding author: deividas.marcinkevicius@ktu.lt

\author{
Гross
}

The process of agricultural collectivization and formation of collective farm villages ${ }^{1}$ started in 1948. There was started an intensive expropriation of land, the intensification of mechanization as well as concentration of the production of agricultural commodities; there was initiated the development of the villages for the newly organized collective farms. During the Soviet period, all villages were classified according to the number of the population in the villages, spheres of control, social and production potential (Bielinskis F., Stanevičius St.). Within the development of new large farming centres, the classification of new villages was introduced according to the functions and administrative division. (The Administrative Territorial... of the Republic of the Soviet Lithuania ..., 1972). The central and secondary villages developed as the derivative structures of the collective farming system or as the principal urban formations. The process of collectivization itself in rural areas together with the industrialization in towns had to serve the increase of economy in the Soviet Union. Afterwards, all the processes related to collectivization significantly slowed down and finally in the nineties of the previous century, were doomed to fail together with the collapse of the Soviet Union.

Keywords: rural landscape, agricultural collectivization, former collective farm.

A huge number of the former collective farm villages as well as rather dense distributher of them throughout the whole territory of the country indicate the impact of those villages on the urban and land management framework of the country. Heretofore, every collective farm village turned to be a guarantee of employment for the population residing in the village because in each collective farm village there were economic-industrial buildings and goods were manufactured by an abundant work force. At present, when a great number of the buildings have been abandoned, the villages have confronted with the urgent problem of unemployment which has caused social problems. The mentioned above problems have derived from one aspect, i.e., the loss of the function of the former collective farm villages. In case, a newly derived function could be provided for those

1 In March of 1948 there was adopted the Party and Governmental Order of the former Soviet Republic of Lithuania 'On the development of the collective farms in the Republic of the Soviet Lithuania'. (K. Šešelgis, 1964; J. Milius, 2005).
JSACE $2 / 19$

Tendencies of Transformations in Rural Landscape of the Former Collective Farm Villages of Lithuania

Received 2017/06/20

Accepted after revision 2017/08/29

\section{Introduction}

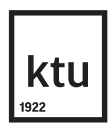

Journal of Sustainable Architecture and Civil Engineering Vol. 2 / No. 19 / 2017 pp. $13-28$

DOI 10.5755/j01.sace.19.2.18426 (c) Kaunas University of Technology 
villages, the issues of unemployment, neglected buildings, impoverishment of the landscape, demographic decline of the population in those rural areas as well as certain social economic problems could be solved.

The objective of the article is to present the scientific research studies on the functional and compositional tendencies in terms of the change of the former collective farm villages located in rural landscape and to derive the summarized findings of those transformations.

\section{Conception and typology of former collective farm villages}

Former collective farm villages in the lithuanian setlement system
Collective farm villages are urban derivatives in the system of farming, which used to be functioning in the former Union of the Soviet Socialist Republics (USSR). They have substituted the previously prevailing system of farmhouses and householders. The previous farms turned to be unhandy for the new political system, because such property as land most frequently occupied a relatively large territory and the communication with farmers was inconvenient, that is to say "when establishing collective farm villages, approximately $6 \%$ of the farming land were occupied by farmhouses with households, buildings and roads" (Gricius, 1990). After the entire farming land of the country has been taken over under the state ownership, all the manufacturing and service centres have been united into a single entity.

Since the middle of the $20^{\text {th }}$ century, together with the intensification of the collectivization reform in agriculture, the villages in rural areas or agricultural settlements of Lithuania have been divided according their industrial dependency, type of industrial relationships and industrial and maintenance character (Šešelgis, 1961, 1996). K. Šešelgis determined the fundamental characteristics of the network of villages, namely "a rigorous subordination of residential areas concerning different rank and mutual dependence. In the planning schemes of the administrative regions there have been provided two ranks of villages located in rural areas, namely villages owned by a separate agricultural enterprise and owned by several collective farms" (Šešelgis, 1996). In terms of the functions to be developed in villages, the classification system was divided into urban and rural settlements of the Soviet Lithuania including all the historical rural areas (small towns, small villages, villages with a church and ethnographic villages) as well as newly established collective farm villages. According to the industrial and social significance, they were divided into the following groups: central, secondary and 'not to be developed² (On giving services to the population of the Soviet Socialist Republic of Lithuania ..., 1986; Šešelgis, 1991, 1996). The author, K. Blaževičius, indicated that "The network and size of collective farm villages were determined by the following criteria, namely the location of industrial complexes and the program on the development of agricultural commodity production" (Blaževičius, 1976).

K. Šešelgis in his work wrote, that " .... the size and location of the centres of the territorial units (towns, villages of a town type and other villages) within the territory had to be determined by the development of economic, industrial, social and cultural factors; the prevailing system of accommodation in the location, natural conditions and characteristics of the landscape" (Šešelgis, 1996). In the plans were developed out for each collective farm, there were indicated several villages called a brigade or team type villages and one central village. That was the way how to establish so called developed villages and of no perspective villages. The latter were expected to be gradually eliminated when consolidating the farms. All the regions of the country were supplied with the plans indicating the following: developed collective farms, forests, greenery, local roads, locations

2 Central settlement/villages, where lives the majority of the inhabitants of the collective farm. There were built administrative, cultural, medical and service centres. Secondary villages are necessary for farms that have large dispersed territory, with complicated natural conditions. They are formed when the inhabitants are moved away from the farmhouses and when building some of the public enterprises. Not to be developed villages are such, which are not perspective and not to be developed when consolidating or specifying the type of industrial production. Such villages do not have public and residential buildings (On giving services to the population of the Soviet Socialist Republic of Lithuania ..., 1986). 
of the villages, industrial centres of collective farms and State owned farms (Fig. 1.). During the Soviet period, the major trend when reorganizing the settlement system of Lithuania was the consolidation of the villages and the decrease of their number (Bučas, 1988). When consolidating farms, there were changed boundaries and sizes of consolidated collective farms. "The development of rural villages in those times was co-ordinated with the collective farms development. The plan was to provide services to agricultural industrial complexes of that period; there was planned the development of about 250 municipal centres to be able to provide service... in each

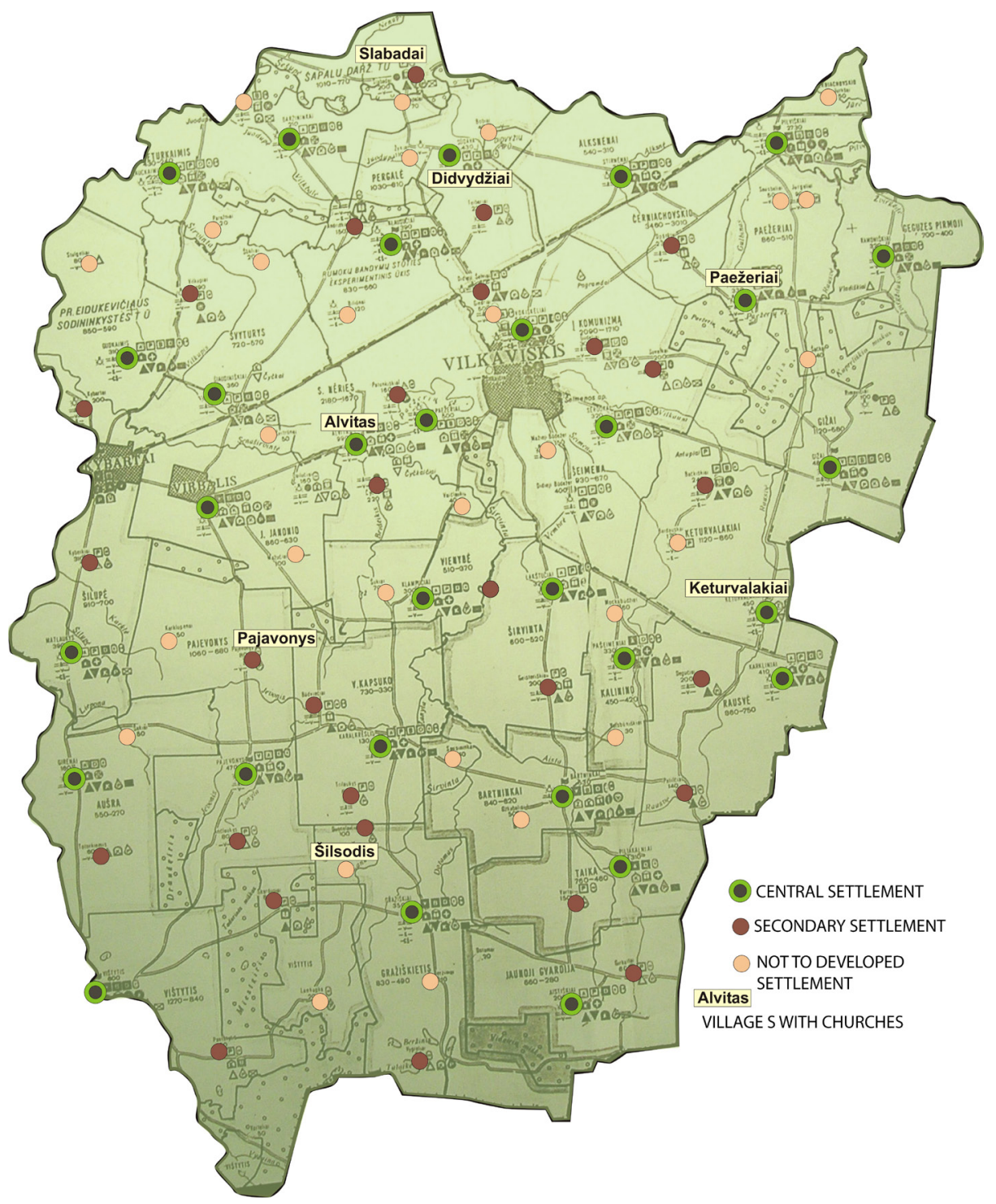

collective farm, taking into consideration local conditions and to develop the network of central and secondary villages. The plans provided that the number of the inhabitants in the central village of the collective farm had to be approximately 500-550" (Kriaučiūnas et al., and others 2015). To develop the above mentioned model of villages. There was prepared the pattern of the regional planning for Lithuania.

According to the type of activities performed, there were applied two major types of collective farms in Lithuania. There were farms for livestock production and crop growing. The two types

\section{Fig. 1}

Distribution of the villages of the former collective farms in Vilkaviškis region (a diagram was compiled by V. Karvelyte Balbierienè, as based on "The scheme of distribution of the establishments for maintenance and services for the population in the rural areas of the Republic of the Soviet Socialist Lithuania" (1989) 
were frequently related to each other, therefore the same farm used to develop at the same time both agronomy and livestock breeding. There were specified farms such as poultry farms and fishery farms and other types of collective farms, but they comprised a very insignificant part in the general system of the collective farms of Lithuania. "In total, in rural areas of Lithuania there were built 500 dairy farms, 3 cattle breeding farms, 3 pig breeding complexes and 27 pig breeding complexes owned by several farms. Besides that, there were built 5 poultry breeding complexes near the large cities" (Bučas, 2001).

\section{The distribution of collective farm villages in the present century of the Republic of Lithuania}

The former collective farm villages are evenly distributed all over the territory of Lithuania. In areas, where natural barriers prevail, there are few villages (e.g. a large area of forest coverage in Dzūkija region or infertile land in East Aukštaitija). Suvalkija has the greatest density of former collective farm villages as well as the Central Part of the country with the most fertile agricultural land. The system of collective farm villages has been reorganized several times during all the period of the collective farms existence. Collective farms have been consolidated and disjointed and made smaller in size within the whole territory of Lithuania. Alvydas Baležentis in his article dated 2011 under the title 'Development of rural areas and their forms: sustainable development approach' determined three stages of collectivization process, which significantly influenced the spreading of collective farms over the territory of the country:

1950 is the period of collectivization, deportation of farmers that resulted into destruction of farmhouses.

1960 is the period of establishing collecting farm villages according to the "team" (unit) principle, destruction of farmhouses; construction sites are allowed only within the territory of the village.

1980 is the period for consolidation of collective farms, because "team" (unit) type collective farm villages appeared to be not perspective. The process of construction works was cancelled in villages. Reclamation of land was the stimulus for destruction of farmhouses.

"There were worked out 940 projects for collective farm villages in the Republic before the beginning of 1959, and 500 were approved. All the collective farm villages had their projects." (Butkevičius, 1980). "In 1975 there were 3089 perspective collective farm villages in Lithuania; 1542 of the total number of the villages were called central villages, 1547 of the total number were called secondary villages. Besides that, there were 780 villages called as "not perspective ones" (Mardosa, 2008). The statistical data indicates in what amount and rates the collective farm villages were established, therefore it is possible to state that the network of former collective farm villages (CFV), had been rather dense in a relatively small territory of Lithuania.

In 1984 new collective farm villages were not established any longer and only few villages were built, then there were registered 736 collective farms in the territory of Lithuania. In different municipalities the numbers differed, starting from 1 in (Šilute region) to 31 in (Marijampole region nowadays). However, in the majority of municipalities there was indicated the following number of the collective farms: from 15 to 20 . The exact number of collective farms was determined by the size of the municipality itself, the size of the collective farm, the fertility of the land in the region and some other factors. In most cases, in a single collective farm, there were 2 or 3 collective farm villages (central and secondary; central and two secondary; central, secondary and not to be developed and etc.).

The same tendency regarding the layout of former collective farm villages (CFV) has remained up till now in the country. (Fig. 2). Thus, the landscape of the country has been under the influence of a great number of the existing CFV and that has contributed to the formation of the identity of the landscape. 


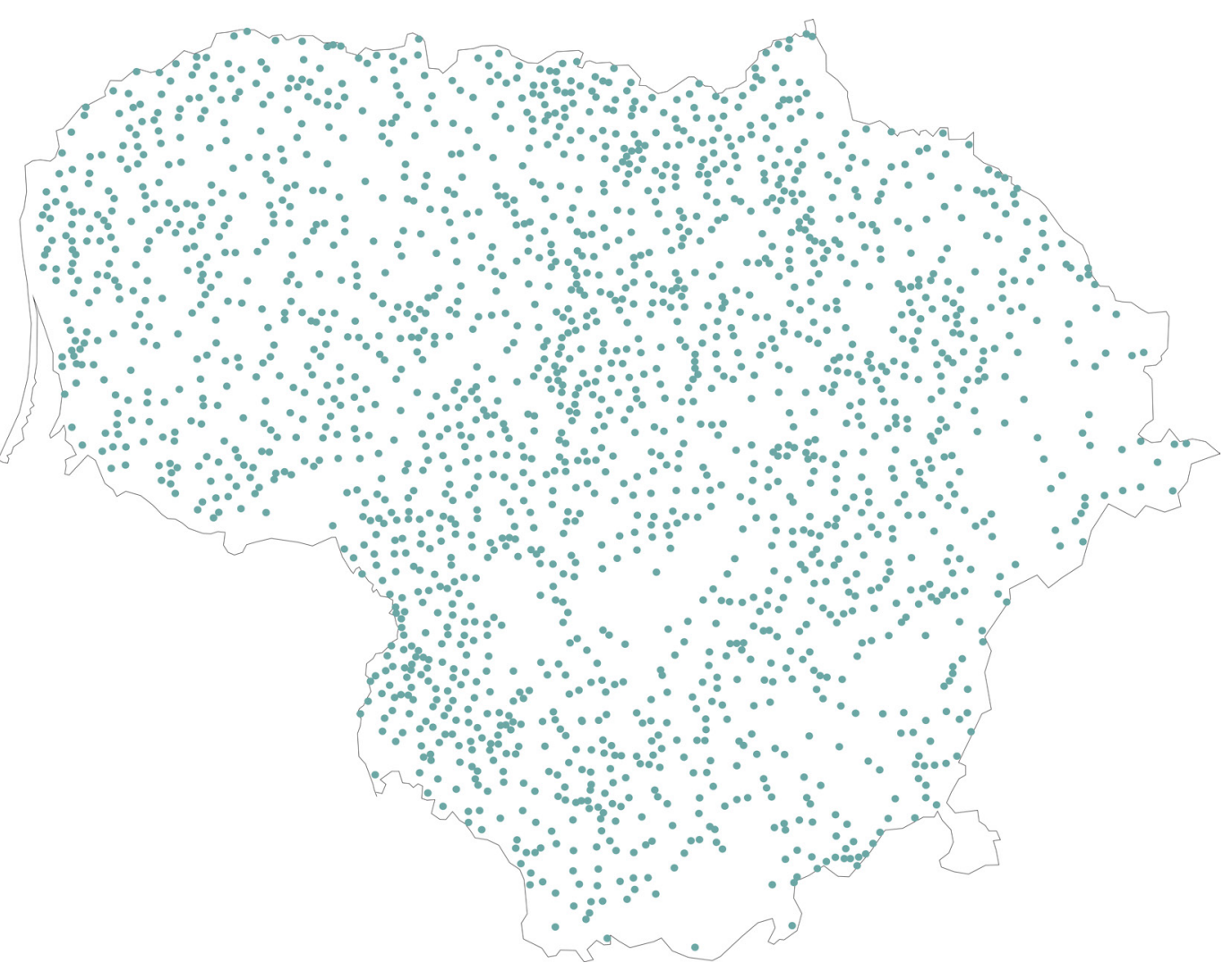

The most important stage, when establishing a new village, is the selection of location, which greatly influences further development of the village and the welfare of residents residing in it. J. Bučas (1988) stated that collective farm villages lack compositional unity and maturity “....newly built villages of collective farms in the landscape of the rural areas look like an accumulation of loose greyish buildings, with a water tower or a flue of the local boiler house stretching out." Two major compositional parts of the collective farm village clearly distinguish in the landscape, namely a residential zone and an industrial zone (Fig.3.). The industrial part of the village is usually considered to be more active in composition; it is possible to find greater diversity in it what concerns forms, volumes, sizes and proportions. The play of volume and form in the residential part of the village is rather moderate; there is more compositional rhythm and monotony.

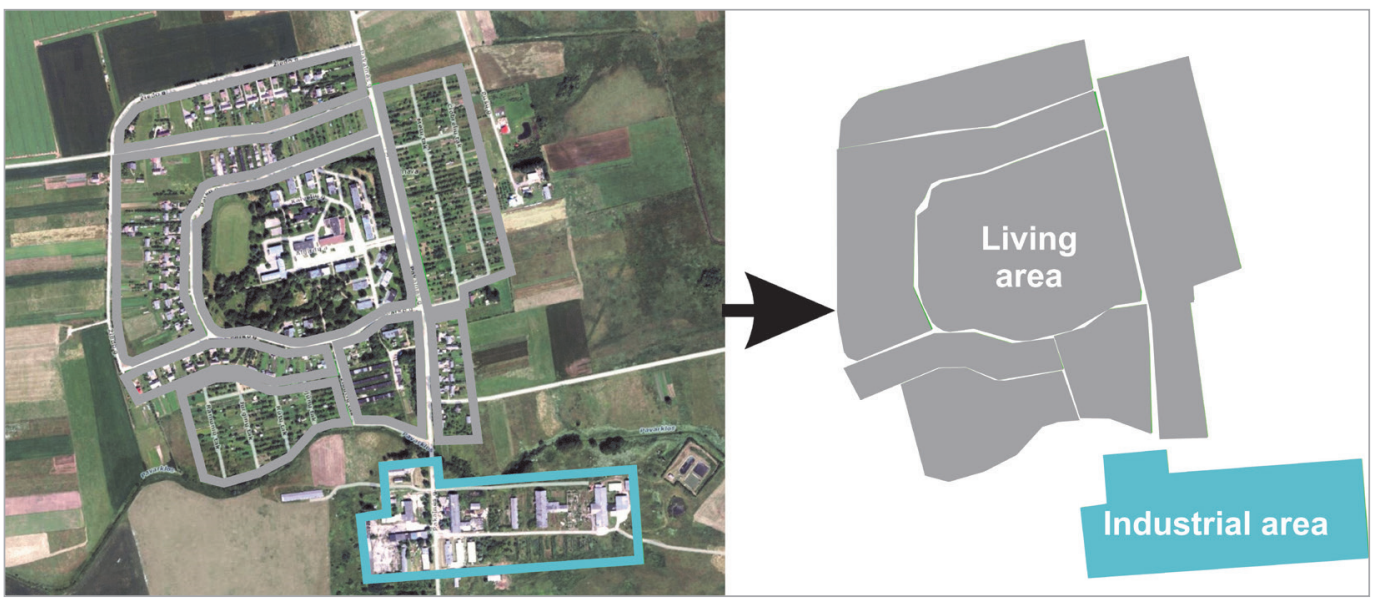

Fig. 2

Distribution of CFV (collective farm villages) in the current territory of Lithuania (in 2017 there are registered circa 1900 villages). Compiled by

D. Marcinkevičius

Compositional characteristics of former collective farm villages in landscape

Fig. 3

Zones of the village. Dainava collective farm village (an exemplary village in Ukmergè region). Compiled by

D. Marcinkevicius 
The landscape of the industrial part of the village distinguishes itself by high and long volume industrial complexes of the collective farm villages. Most frequently they are tall and massive elevators and silos towers, which used to be built in sorted groups. Those towers are frequently dominating in the panoramic view of the village, overshadowing such important historical dominants of the landscape as the towers of churches. Moreover, water towers distinguish themselves by their height in the industrial zones, supplying water to the industrial part of the village; the same is with chimneys and the other towers and structures. But the buildings are significantly smaller in volume if compared with the elevators and silos towers. Animal farms distinguish themselves by their length, space and extent they occupy, they are used for keeping cattle. Storage depots or barns were used for hay, straw and other harvested cultures. They most frequently do not single out by their height, but in the landscape they are highlighted by their huge volume and their horizontality.

Nowadays, the buildings and structures in the majority of industrial zones of the former collective farm villages are desolate, degraded and completely destroyed. The ruins of animal farms, storage barns or other buildings discord in the landscape, impoverish it and make it unattractive. In some places, the ruins are overgrown with bushes and trees, but the contrast with the landscape is not so intense. A great number of tall dominants have been destroyed, especially water towers and buildings made from metal structures.

In most cases, the residential zone of any collective farm village has a water tower as the only dominant. At present, in villages where water supply systems have not been renovated so far, water towers tend to continue their direct and prescribed purposes. What concerns the landscape, some parts of residential areas in villages have integrated in a rather moderate way, there are no huge capacity structures, which distinguish themselves by their dimensions. Because of their so-

Fig. 4

Pitched roofs prevail in a former CFV. (http:// www.miestai..., 2016)

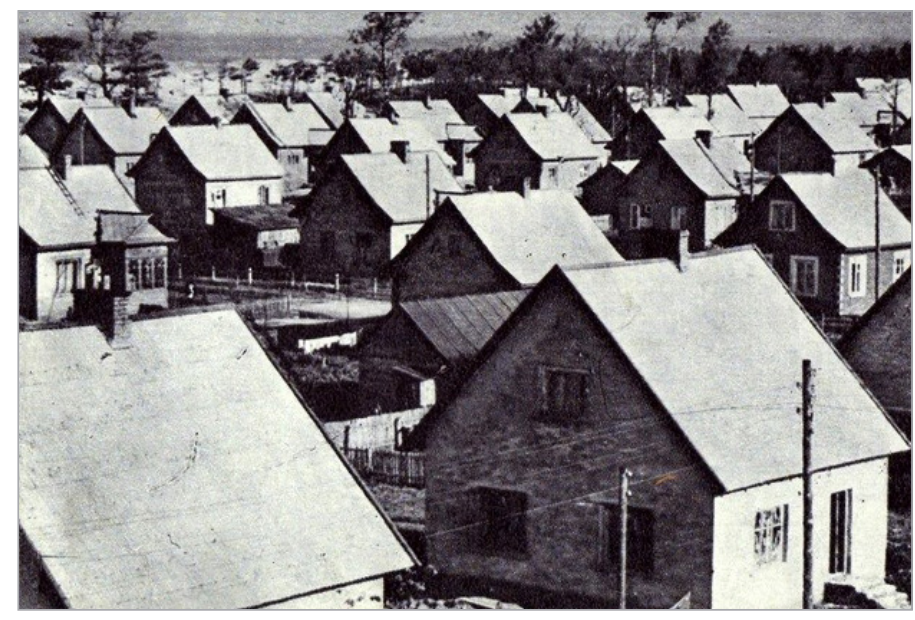

Fig. 5

A serial mass construction in a CFV

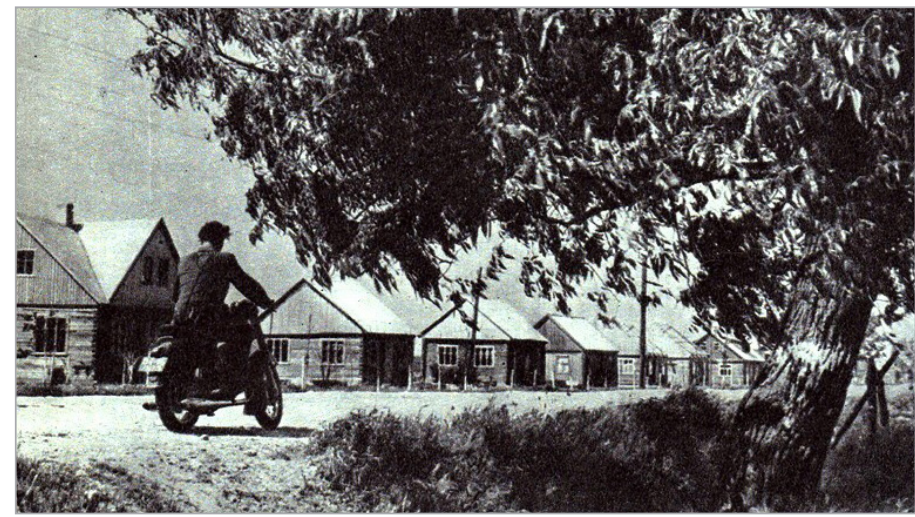

cial purpose, local schools, cultural centres, apartment buildings were usually designed as having large capacities. But their volumes have been subdivided in order to be visually smaller.

The rhythmical layout of similar and homogenous houses in the residential part of the village and the jagged horizon of pitched roofs form the silhouette of the landscape (Fig. 4.). In the collective farm villages the same as in towns, the standartized (typed) structures was applied (Fig. 5.). In most cases, the houses of same type were built in a large part of the village and even in different villages. That fact predetermined the similarity not only inside the villages, but in the landscape, as well there was felt the lack of exclusivity. 
Nowadays, the houses of former collective farms are being renovated individually and personally, therefore it is necessary to discuss the new possibilities for the renovation of such villages and to legitimize certain regulations on architectural renovation of villages, which could provide and ensure a visual and architectural quality.

\section{The applied methods of research}

When investigating the objects i.e., the villages of former collective farms, there have been applied three types of methodology. They include the methods of sociological surveys, investigation on the site and visual characteristics of landscape.

Methodology of sociological survey. The survey was divided into two parts, namely the surveys conducted in the communities of the villages and surveys conducted with professional architects. The sociological surveys conducted for the community members of the villages have been carried out in the rural areas of Kaunas region. Surveys conducted with experts included the questionnaires for the experts of architecture, practitioners dealing with urban problems. The answers received would assist in finding out the opinion and judgements based on two groups of respondents in terms of the former collective farm villages, the realistic situation there and the impact on landscape, architecture; they would explain functional and urban problems. The questionnaires contained a certain part of similar questions both for the members of local communities and for experts; there was an attempt to perceive the main differences of opinions on certain issues. The sociological surveys revealed a) the opinions on the possibilities of functional practical adaptability of former collective farm villages; b) the existing attitudes on the architectural/urban value of CFV (collective farm villages); c) the proposals in what way and manner the CFVs have to be renovated; d) the ideas, what architectural stylistics could be most appropriate for renovation of CFV; e) the concepts on the new function of usage of industrial buildings.

Methodology of visual characteristics of landscape. The method of landscape visual characteristics (following J. Bučas method) made it possible to determine the main specific visual-panoramic aspects of the villages. Besides that, they would allow to determine the level of landscape identity of the investigated objects, the lack or surplus of it. The applied methodology would be able to identify visually the most problematic places of the analysed objects. By applying the method of visual characteristics for the analysed objects, the attempt has been made a) to evaluate spatial-compositional structure of the objects in the landscape; b) to determine the places where visual elements are in abundance or in shortage; $c$ ) to define the valuable panoramic elements of the objects; d) to mark out the problematic places, which in future could be solved; e) to determine the zones of impact of dominants and landmarks.

Methodology applied on site. When practising this research method, the physical depreciation of objects is determined as well as the current situation; photo fictions are made, with the help of which, the attempts are made to distinguish the positive and negative aspects of objects. The potential of the functional usage of the objects is singled out.

Selection criteria applied for the objects CFV (collective farm villages): a) geographic location - a feasibility study is made and selected CFV, that are located not far (up to $20 \mathrm{~km}$ ) from the centre of the region or in the peripheral zone of the influence of the territorial counties; b) physical condition the analysis is made concerning the villages having the preserved buildings of the complexes of the industrial zones and over a long period of non-use the buildings have not been eroded away; c) size - the analysis of villages with a greater attention paid to the zones of industrial complexes with a set of several buildings. The residential zones of the villages would not be under the great influence, the main requirement would be that residential zones could not be in the villages with the status of a small town; d) type - the analysis of central and secondary villages of the former collective farms; but there is no analysis regarding 'the not to be developed villages', because of their too excessively
The results of the reseach on the tendencies of transformations of former collective farm villages in landscape 
low urban structure; e) landscape value - the analysis of the visually active former collective farm villages, having an average or significant influence on the landscape; f) engineering infrastructure with an access to the object - the analysis of the former CFV located at the highways or at the asphalt -covered roads; g) use of an object - the analysis of a former CFV having a greater number of industrial buildings which have not been used at present or only partly used or have not had any active manufacturing performance; l) urban structure - the analysis of the former CFV where the zones of industrial and residential functions have been clearly distinguishable.

The villages in Kaunas region have been selected for the research studies. The General Plan of the Republic of Lithuania singles out the territory as the zone of the intensive economic processes. The region is linked with the principal transit highways connecting important centres of the region (Prienai, Kaišiadorys, Jonava, Kedainiai). Taking into consideration, the boundaries of the impact zone of agglomeration and the influence of the centres existing around Kaunas, there has been compiled the distribute of the former CFV with central and secondary villages. In accordance with the main criteria of the selection (geographic location of an object, it's physical condition, size, type, value of the landscape, engineering infrastructure with access roads to an object, the application of an object, urban structure) there have been chosen the following collective farm villages for further investigation, namely 2 located in Jonava region and 1 in Kaunas region. They are Čičinai and Ručiūnai in Jonava region and Didžiosios Lapès in Kaunas region.

\section{Results of sociological survey regarding the former collective farm villages}

The questionnaires for the members of the communities were distributed in Kaunas and Jonava regions. There were 75 respondents or 30 men and 45 women who conducted the survey. The majority of the participants of the survey (27 participants or $36 \%$ ) were from 30 to 45 years old, i.e. they were middle aged. Their general opinion regarding the former collective farms and their tangible assets has been impartial and uninfluenced by the experience gained from the Soviet period. There were two groups of senior residents, aged from 46 to 59 and from 60 to 79 year old. Each group had 19 respondents (about $25 \%$ ). The smallest groups participating in the survey were from 18 to 29 years old ( 5 respondents) and the most senior participants were from 80 years old and even more ( 3 respondents). There were received 25 answers from the group of experts; they were architects, experts of urban construction, professionals in heritage protection and the master degree students or post graduate students of architecture.

The majority of the answers to the analogues or similar questions among the respondents representing communities and expert group coincided or slightly differed. The questions, which required professional or deeper knowledge, received the most difference of opinions. Here comes one example. The question concerned the architecture of the industrial buildings of the former collective farms after renovation and modernization. The members from the communities selected the answer about modern architecture, while the experts stated that the complexes have to be of a mixed architecture style, a mixture of traditional and modern architecture. However, all the respondents unanimously agreed that former collective farm villages of Lithuania require new approach towards renovation and functional adaptation.

The respondents from the communities underlined that the most urgent problem was unemployment; they wanted new jobs to be created in the villages. They pointed out the unused former industrial buildings, which could be justified, in case the functions of various types of industrial production could be established, and new workplaces could be created.

Besides that, a great part of respondents considered, that the physical and functional conditions of abandoned and unused industrial buildings in those villages at present, had to be evaluated, but there had to be demolished only those buildings that were considered to be completely unusable. The remaining buildings had to be preserved, modernized and adapted to different functions. Nearly $70 \%$ of the respondents expressed the idea, that a certain part of former industrial 
buildings and structures, previously used for farming purposes, and a certain part of structures, located in the residential zones of the former collective farm villages, such as cultural centres, educational institutions and etc., had preserved their historic and architectural value.

The respondents also underlined the idea of the financial support from the governmental institutions when renovating the residential buildings in villages, they proposed that the same way could be applied as it had been used in towns of the country regarding the renovation of multi-storied buildings. They wanted their residential buildings to bear a homogenous architectural style, to be able to create visual and architectural harmony in the village.

After summarizing the results of the survey, it is possible to state, that in the former collective farm villages, there prevail the absence of functionality, which causes the consequences as well as other problems considered as relevant, acute and painful. The majority of the respondents approved the statements that former collective farm villages had to be revived, renovated, as well as the former industrial complexes had to be granted a new function.

\section{Research of the visual characteristics collective farm villages of in landscape using by J. Bučas method}

Ručiūnai village. After carrying out the analysis of the compositional structure of two silhouettes of the village in the landscape from diverse points of the review points (Fig. 6), it was clarified, that the red line of development of the village horizon indicated the relatively even and moderate height of the village development. On the left side of the view was clearly seen the industrial zone of the village, distinguished by its height from the remaining part of the village. The elevator tower as a dominant was standing out in the same zone, and was the main dominant not only in the outlook of the village but in a wider sense of the surrounding environment. In Ručiūnai, there prevailed the standardized principle of urban grouping used in collective farm villages, when two main zones of the village (residential and industrial) were built separately within a certain distance from each other. The standardized version was used mostly due to binding health standards and norms. Those two zones of the village were located within the distance of $0.5 \mathrm{~km}$ from each other. From the first panoramic point of the village the zones seemed not to obstruct each other, but compositionally to supplement each other.

Čičinai village. The residential part of the village has been developed mostly by single family houses following the so called 'Alytus' standard. The industrial zone of the village distinguishes itself by having a close link between the residential part and the industrial one. The industrial zone has buildings of various heights which makes the silhouette of the village playful but not monotonous. The panoramic views of the village (Figs. 7,8 ) indicate one principal dominant i.e. an elevator.

The other structures such as warehouses for storage, towers made of metal lattice, power transmission lines, a chimney, located in the industrial zone of the village are only the additional focus points in the skyline of the village. From the point of view of composition, the layout of the residential and economic zones of the villages is not considered to be successful, because there, on the west and north sides of the village, dominate only industrial-economical zone. We get the impression that we see a desolate industrial zone, which has moved away from the town and has been built somewhere in the middle of the fields. The functional zoning of the village is not easy to grasp visually.

Didžiosios Lapès village. The location for the collective farm village was chosen in the former historical small town. The village is surrounded by an impressive landscape that is famous by plenty specific forms of the relief, diverse levels of height. The residential part of the village is located on both sides of the main road of the area and in the upper part of the village. The former industrial zone of the village is located within $1 \mathrm{~km}$ on the north of the residential zone, in the lower part of the village (Fig. 9). 
Fig. 6 RUČIŪNAI VILLAGE

Analysis of landscape characteristics in the panoramic view of Ručiūnai village (from 1 photo fixation point) Compiled by

D. Marcinkevicius
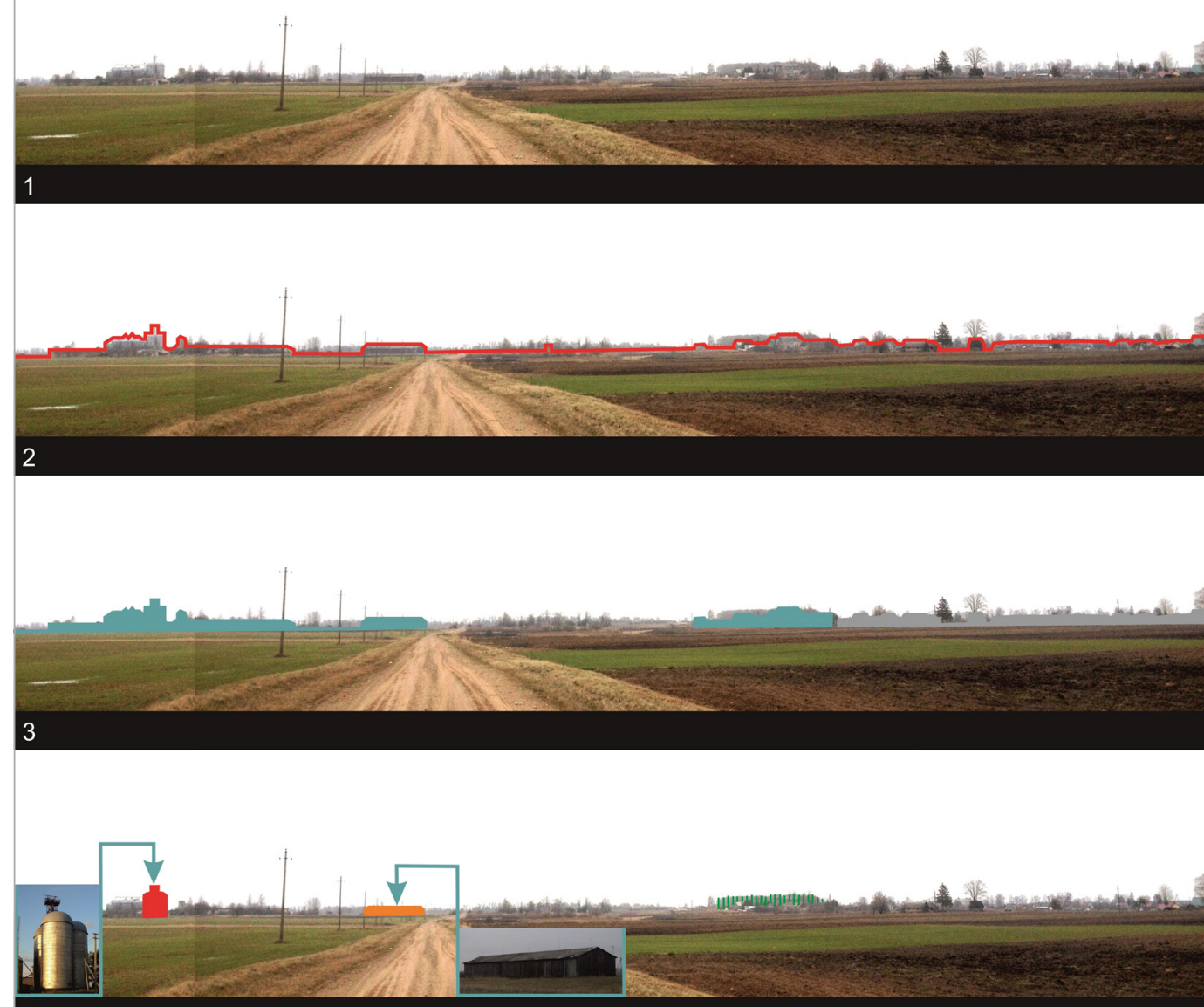

4
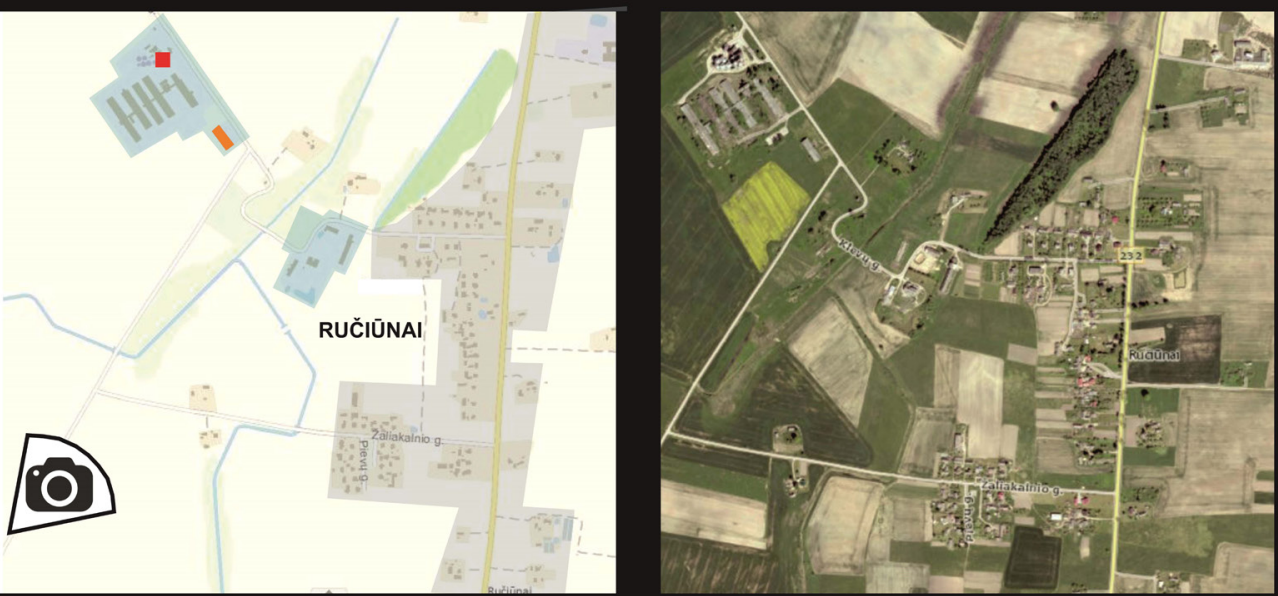

5
1. Panoramic view.
4. Dominants and focus points.
2. Contour of layout.
5. Village layout and an ortpho-photo.

3. Layout of industrial and residential zones. 


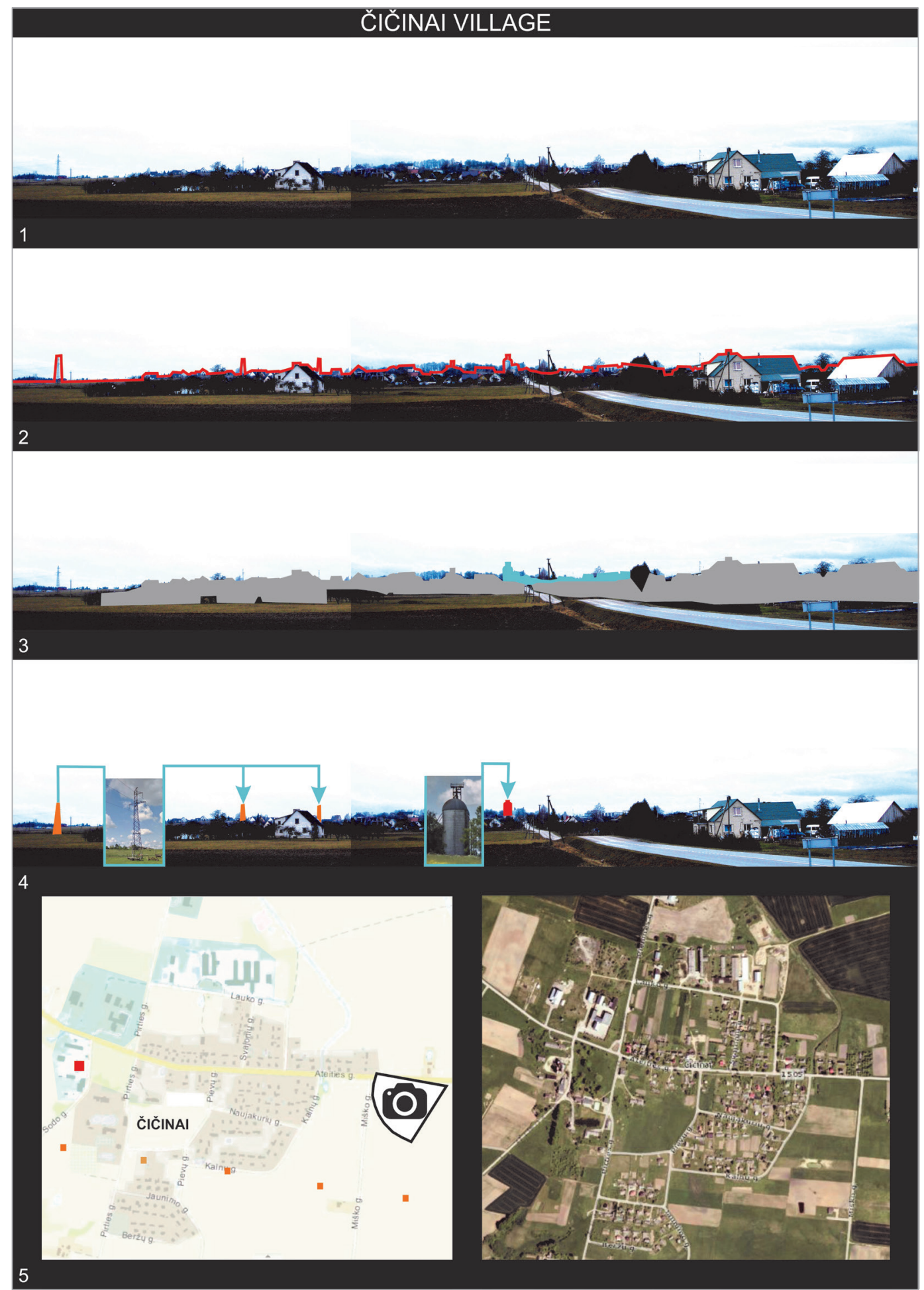

Fig. 7

Analysis of landscape characteristics in the panoramic view of Čičinai village (from 1 photo fixation point): Compiled by $\mathrm{D}$. Marcinkevicius

1. Panoramic view.

2. Contour of layout.

3. Layout of industrial and residential zones.
4. Dominants and focus points.

5. Village layout and an ortpho-photo. 
Fig. 8

Analysis of landscape characteristics in the panoramic view of Čičinai village (from 2 photo observatory point). Compiled by D. Marcinkevicius
ČIČINAI VILLAGE
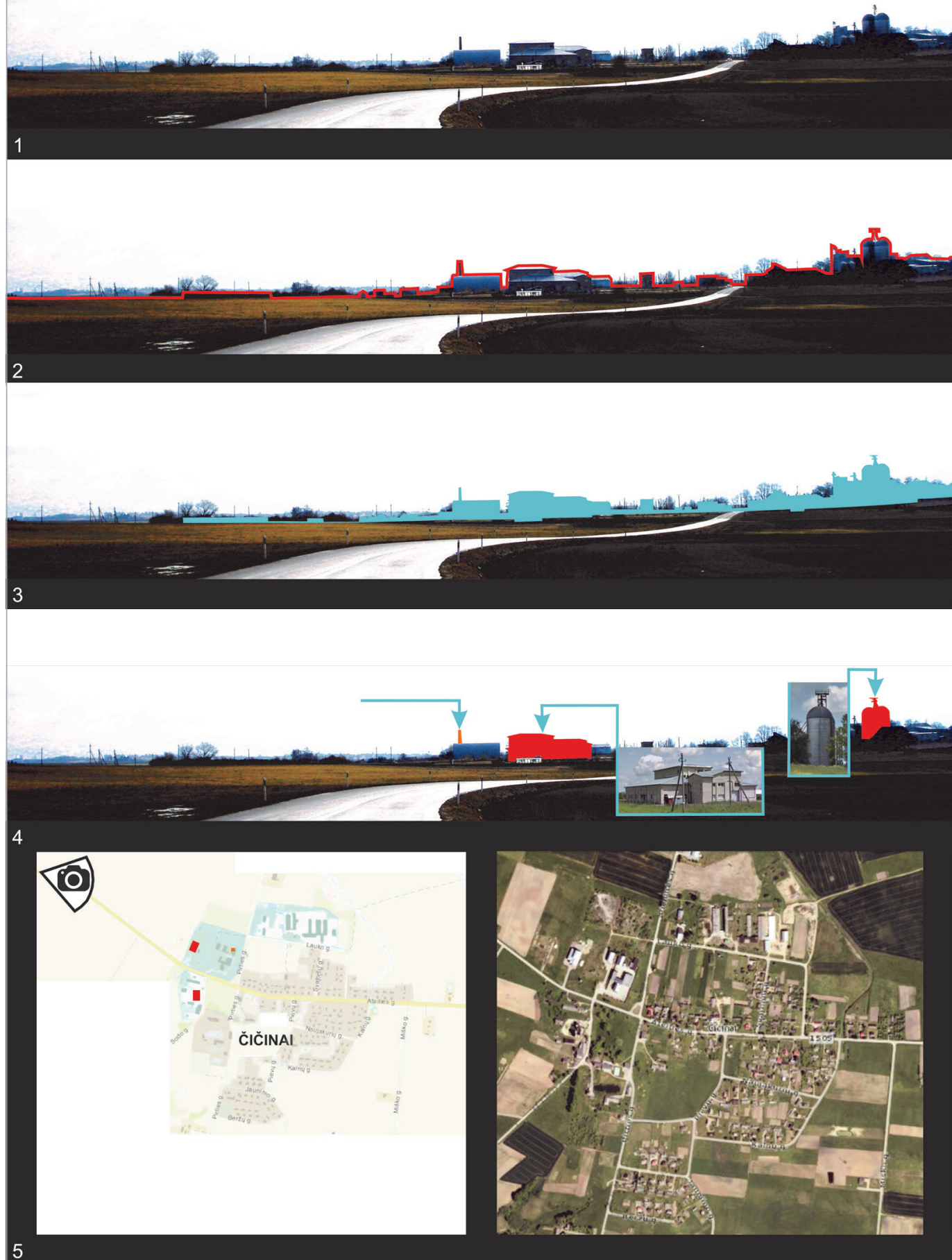

1. Panoramic view.

4. Dominants and focus points.

2. Contour of layout.

5. Village layout and an ortpho-photo.

3. Layout of industrial and residential zones. 


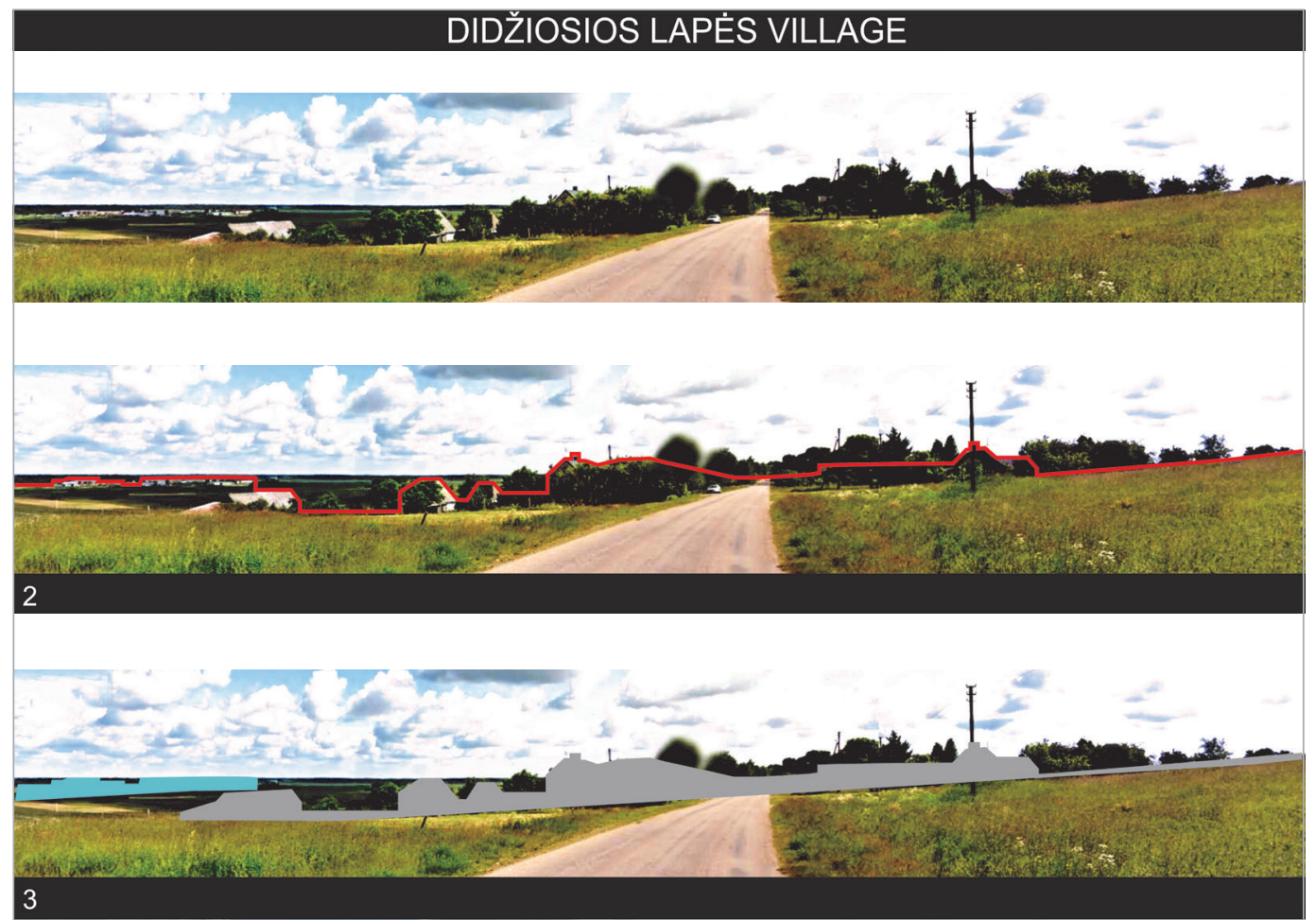

Fig. 9

Analysis of landscape characteristics in the panoramic view of Didžiujjų Lapių village (from 1 photo fixation point). Compiled by D. Marcinkevicius

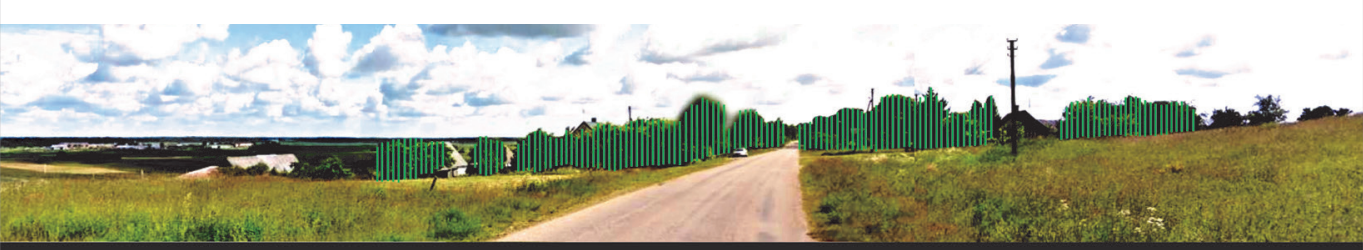

4
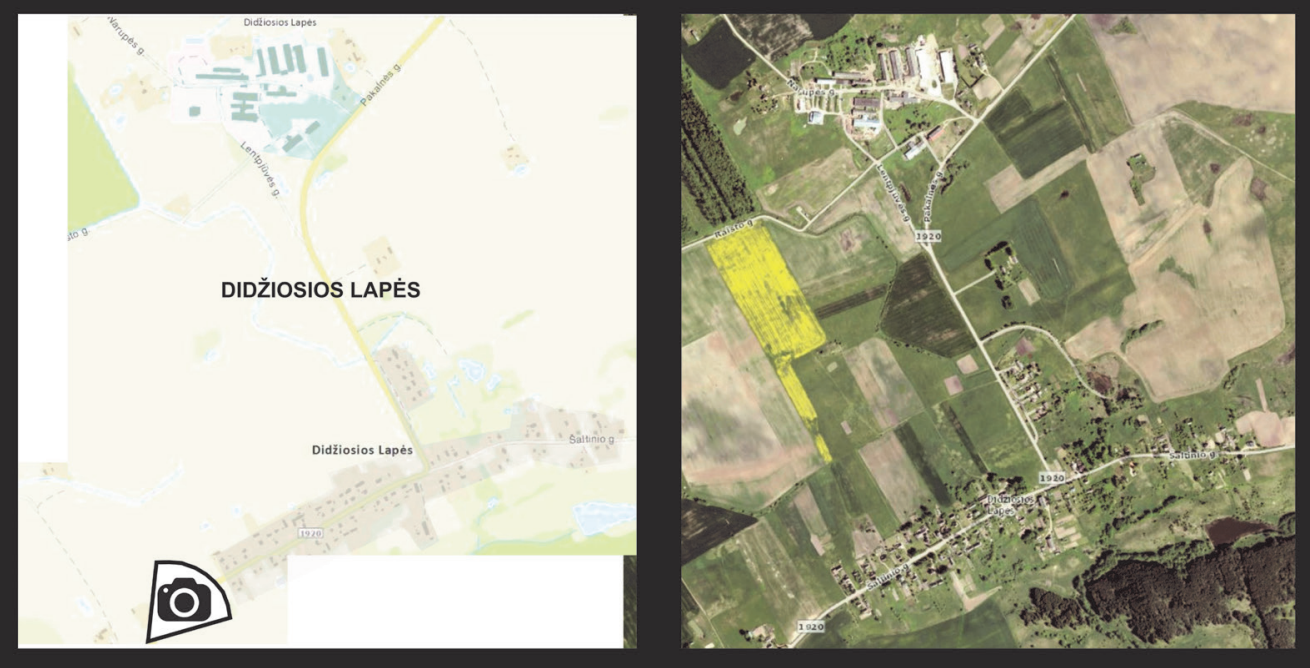

1. Panoramic view.

2. Contour of layout.

3. Layout of industrial and residential zones.
4. Dominants and focus points.

5. Village layout and an ortpho-photo. 
The industrial zone occupies a relatively large territory and visually is bigger than the residential zone, but in reality it occupies the territory that is half of the residential zone. The village singles out by the integrity of its silhouette in the landscape. The only focus point is a water tower, which is not tall and which is located on the southwest of the village. There are no dominants and focus points in the industrial zone, because all the buildings in the industrial zone are of large scale, massive but their sizes insignificantly differ from each other. However, the shortage of landscape dominants and focus points is not felt there, because the height and hilly terrain compensate the view. The farms in the residential zone of the village have been richly planted with large trees, which act as a background and an element creating closeness.

After having summarized the results of the research on the visual characteristics in the landscape of the former collective farm villages following J. Bučas evaluation method on landscape characteristics, it is necessary to inform that the villages have been designed by the same fundamental principles as when applying standardized constructional processes. They visually look different because of the various peculiarities of silhouette in the landscape. The compositional characteristics of the villages in the landscape greatly depend on the type of the elements of nature, namely terrains, abundance of greenery and etc. From the point of view of composition, the skylines of the villages have been designed better, i.e. the residential and industrial zones have been located within a distance and without blocking each other, which has supplemented better apprehension of the functionality of the zones, their purpose and scale of the buildings.

After having investigated the unbroken view of Ručiūnai, Čičinai, Didžiosios Lapes villages, the most successful and best compositional characteristics in the landscape have been exhibited in Ručiūnai village, where all the most fundamental elements of the landscape could be found or in other words there is one principal dominant, several focus points, a small forest creating insularity (Fig. 7). The functional zones of the villages have been separated and visually do not obscure each other; their mission could be easily perceived.

1 The former collective farm villages could be defined as the urban centres built in the Soviet period, having a single function to provide service within a certain territory allocated for agriculture development and prescribed for the village. The former collective farm villages are considered to be the most widely spread urban structures throughout territory of Lithuania. However, the shortage of data concerning the collective farm villages is felt in the literary sources. The number of scientific research studies is not sufficiently enough to have a more extensive analysis of the characteristics of their development as well as the examination of the problems.

Currently, the former collective farm villages have already lost their initial function and a great number of villages have not attained any other new functions. Huge and abandoned former industrial structures used for farming are collapsing nowadays. Unemployment prevails in the villages and the number of the population tends to decline rapidly causing majority of social problems. Making judgements from urban, landscape, and architectural points of view, the most problematic are considered the buildings and structures of the industrial -farming complexes of the former collective farm villages, the largest proportion of which, have been completely abandoned and are falling down. Those farming complexes have turned into the active visual objects of pollution within the surrounding landscape.

3 The sociological research studies have proved that renovation, modernization of the for3 mer collective farm villages and especially the adaptation of the former industrial farming centres for the current and future needs is relevant. The communities feel the shortage of workplaces and new jobs, which were ensured in each former collective farm village and which could be revived and adapted in the premises of the former industrial farming complexes. 
Former collective farm villages require new conception to be brought to life again and 4 adjusted to current functions. The most potential are former collective farm villages that are located the peripheral influence zone of the largest cities of Lithuania with the access roads close to the more significant infrastructure in terms of services or communications. The objects have to be big enough, consequently located in urban territory to be in a relatively good physical condition in order to justify the cost-based renovation, adaptation or modernization of the unused industrial farming buildings of the former collective farm villages. The industrial farming complexes located in the former collective farm villages could be adapted to unusual multifunctional activities. However, the number of such samples to be adapted has to be insignificant and they have to be located not far from the main regional centres. It is considered that the greater number of such centres could not be sufficiently effective within a limited domestic market.

Baležentis A. Kaimo vietovių raida ir modeliai: darnaus vystymo požiūris [Management theory and studies for rural business and infrastructure development] 2011; 2 (26): 1-9. (Accessed 18 Nevember 2016). Available at: http://etalpykla.lituanistikadb.lt/fedora/objects/LT-LDB0001:J.04 2011 1367175156724/datastreams/ DS.002.0.01.ARTIC/content

Bielinskis F., Stanevičius St. Lietuvos TSR žemès ūkio gyvenvietes kuriantieji veiksniai ir ju reikšmè praktikoje [Developing factors of Lithuanian SSR's agricultural settlements and their significance in practice]. Lietuvos TSR architektūros klausimai, 1966; 3: 5-18.

Blaževičius K. Lietuvos kaimo pertvarkymas 1946 - 1970 metais [Reorganization of the Lithuanian village in 1946 - 1970]. Lietuvos TSR architektūros klausimai, 1976; 5(1): 4-35.

Bučas J. Lietuvos kaimo kraštovaizdžio raida ir istorinès vertybės. Vilnius: Mokslas; 1988.

Bučas J. Kraštotvarkos pagrindai. Kaunas: Technologija; 2001.

Butkevičius I. Lietuvos socialistinio kaimo gyvenviečių formavimasis, 1952-1978. Vilnius: Mokslas; 1980.

Gricius V. Lietuvos vienkieminès apgyvendinimo sistemos likvidavimo raida 1967-1985 metais [Development of the Lithuanian farmsteads accommodation system liquidation 1967-1985]. Urbanistinis ir rajoninis planavimas, Vilnius: Mokslas; 1990; 16: 16-36.

Kriaučiūnas E., Krupickaitè D., Pociūtè-Sereikienè G., Ubarevičienè R. Lietuvos kaimo gyvenviečių funkcijų kaitos regioninès ypatybè [...] Geografijos metraštis, 2014; 47: 1-18. (Accessed 10 September 2016). Available at: http://www.gamtostyrimai.lt/uploads/publications/docs/11800_ab0f408b75b6474d240da2ff358c457b.pdf

Lietuvos TSR administracinio teritorinio suskirstymo žinynas [The Administrative Territorial Break- down Guide of the Republic of the Soviet Lithuania]. Vilnius: Mintis; 1972; 2: 396.

Lietuvos TSR kaimo gyventoju aptarnavimo istaigu ir imoniu išsidèstymo schemos [The scheme of distribution of the establishments for maintenance and services for the population in the rural areas of the Republic of the Soviet Socialist Lithuania]. 19861989. Respublikinis žemètvarkos projektavimo institutas. Kauno Žemètvarkos skyrius.

Mardosa J. Lietuvos gyvenvietès ir kaimai 19762006 m: demografinis tyrimas [Lithuanian rural settlements and Villages 1976-2006: Demographic study]. III-oji nacionalinè mokslinè konferencija, Kaimas Lietuvos istorijoje: kraštovaizdis, bendruomenè, gyvenimo būdas, 2007 gruodžio 7. Lietuvos edukologijos universitetas; 2007; 62-70.

Milius J. Valstybės kryžkelès ir žemės reformos [State Crossroads and Land Reforms]. Mokslas ir gyvenimas, 1998; 4: 3-4.

Šešelgis K. Žemès Ūkio gyvenviečių optimaliu dydžių klausimu [On the optimal size of agricultural settlements]. Lietuvos TSR architektūros klausima, 1964; 5(2): 117-125.

Šešelgis K. Lietuvos kaimo gyvenviečių tipologijos klausimai [Typology issues of Lithuanian rural settlements]. Urbanistika ir rajoninis planavimas, Vilnius: Mokslas; 1991; 17: 84-59.

Šešelgis K. Teritorijų planavimo raida Lietuvoje [Development of Territorial Planning in Lithuania]. Urbanistika ir architektūra, 1996; 1: 4-28.

Šešelgis K. Lietuvos TSR gyvenviečių tipai [Lithuanian SSR types of settlements]. Statyba ir architektūra, 1961; 1: 187-205.

Šešelgis K. Apie Lietuvos TSR gyvenviečių tinklą ir jo tyrimu metodiką [About the methodology of Lithuanian SSR residential networks research]. Statyba ir architektūra, 1996; 2: 181-207.

http://www.miestai.net/forumas/showthread. php?t=12143 (Accessed 10 September 2016). 


\section{About the authors \\ DEIVIDAS MARCINKEVIČIUS \\ Master student}

Kaunas University of Technology, Faculty of Civil Engineering and Architecture, Departament of Architecture and Urbanism

\section{Main research area}

Protected rural landscapes

\section{Address}

Studentu 48, LT-51367 Kaunas, Lithuania Tel. +370451546

E-mail: deividas.marcinkevicius@ktu.lt

\section{VILMA KARVELYTÉ BALBIERIENE்}

Assoc. Professor

Kaunas University of Technology, Faculty of Civil Engineering and Architecture, Departament of Architecture and Urbanism

\section{Main research area}

Protection of cultural heritage; research of small towns and ethnographic villages

\section{Address}

Studentu 48, LT-51367 Kaunas, Lithuania Tel. +37068236358

E-mail: vilma.karvelyte_balbieriene@ktu.lt 